\footnotetext{
${ }^{1}$ Research Institute for Animal Breeding and Nutrition, Herceghalom, Hungary

${ }^{2}$ Research Institute for Agricultural Quality Control, Budapest, Hungary
}

\title{
Do Mangalica Pigs of Different Colours Really Belong to Different Breeds?
}

\begin{abstract}
The genetic relationships among the indigenous Hungarian Mangalica swine breeds in farms at different geographical locations have been studied by ten microsatellite markers (S0005, S0090, S0101, S0155, S0355, S0386, SW24, SW240, SW857, SW951), in order to characterise the population and to give sound scientific basis for management practices. The work hypothesis - that Mangalica individuals form just one unpartitioned population - has been rejected. The estimated value of clusters in population is three and it is in content with the history of the breeds. The estimated distances (Ds, Da, Fst) were the smallest between Swallow-Belly and Blond, while the Red showed the largest genetic distance from the previous two breeds. This approach proves the existence of distinct populations and can be used for assignment of individuals with high probability value (in the range from 0.83 to 0.91 ) to the different Mangalica breeds if required.
\end{abstract}

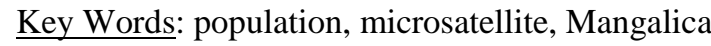

\section{Zusammenfassung}

Titel der Arbeit: Gehören Mangalitzaschweine mit unterschiedlicher Färbung wirklich verschiedenen Rassen an?

Die genetischen Beziehungen zwischen einheimischen ungarischen Mangalitzaschweinen unterschiedlicher geografischer Herkunft wurden mit Hilfe von zehn Mikrosatellitenmarkern (S0005, S0090, S0101, S0155, S0355, S0386, SW24, SW240, SW857, SW951) untersucht, um eine wissenschaftliche Basis für die Zuchtpraxis bereitzustellen. Die Arbeithypothese, dass Individuen der Mangalitza-Schweinerasse eine einheitliche Population darstellen, wurde verworfen. Es wurde geschätzt, dass innerhalb der Population drei Gruppen existieren. Diese Beobachtung stimmt mit der überlieferten Entstehungsgeschichte der Rassen überein. Die geschätzten genetischen Distanzen (Ds, Da, Fst) waren zwischen schwalbenbäuchigen und blonden Mangalitzaschweinen am geringsten, während rote Mangalitzaschweine die größte genetische Distanz zu den beiden anderen Rassen aufwies. Die Untersuchung beweist die Existenz getrennter Populationen und kann dazu genutzt werden, Individuen mit hoher Wahrscheinlichkeit (im Bereich von 0,83 bis 0,91) den verschiedenen Mangalitza-Rassen zuzuordnen.

Schlüsselwörter: Population, Microsatelliten, Mangalitza

\section{Introduction}

It is widely accepted that the Lápi pig breed, kept by the Avar people (a.d. 800-900), from the Carpathian basin, might have been the predecessor of Mangalica breed group; Bakony, Szalonta, Alföldi (EGERSZEGI et al., 2003). Documental sources refer that in the $19^{\text {th }}$ century (1833), animals of these breeds started to be crossed with Serbian Sumadia pigs (ENESEI DORNER, 1925). Probably Blond type had been formed first, and then it was crossed by Black Croatian Szirmium/Szeremier pigs (CZILERT, 1859). Black disappeared at the end of the 19th century and set the Swallow-Belly with black hair but blond throat and underbelly. In the second part of the 19th century 
Blond sows were coupled with Szalonta boars resulting in Red Mangalica (HANKÓ, 1940).

In 1927, all the production values of Mangalica started to be recorded and last until the Second World War. During this world conflict the control of this breed was lost and the population went through a drastic decrease. As a counteract strict national conservation program has been started in Hungary in the 1950s mainly based on phenotype. In 1973, the Hungarian state considered Mangalica under protection, however a second period of disorganization occurred in the 1990s due to reorganization of the agricultural sector. Fortunately the Mangalica was rediscovered due to its adaptability to stress and disease resistance, motherliness and taste of its meat (MICKLICH et al., 1999). A large commercial project has also been created in 1991. As a result nowadays the market requires steadily increasing amount of Mangalica products. The current numbers of Mangalicas in Hungary are; Blond: 2289, Swallow-Belly: 450, Red: 603. There are mentionable populations of Mangalica in Switzerland, Germany, Austria and some breeding animals are kept in Romania and in area of the former Yugoslavia (EGERSZEGI et al., 2003).

Beyond parentage control based on blood groups or properly written herdbooks, farmers have the possibility to gain more detailed information on genetic diversity and distance of their breeds using molecular genetic data. One way to access molecular genetic information is to type microsatellites which has already been used successfully in of cattle (HANDIWIRAWAN et al., 2003; MAUDET et al., 2002), sheep and goat (JANßEN et al., 2004; ) donkey (JORDANA et al., 2001), horse (ABERLE and DISTL, 2004) and pig (NECHTELBERGER et al., 2001; SCHWARZ et al., 2005) as well.

This study aims to assess the genetic relationships between Mangalica breeds and individuals based on microsatellite typing.

\section{Materials and Methods}

Predominantly those farms (15) and individuals (282) were selected for analysis, which have contributed to the 'genetic maintenance' with a great extent and have been used for creating new Mangalica herds. Nearly all breeding boars and sows from Swallow-Belly (SM) and Red Mangalicas (RM) have been analysed (73, 86), and from Blond Mangalica (BM) blood 123 samples were collected according to our predefined plan into EDTA coated tubes. Duroc blood samples (67) were also collected from different farms as a control.

Microsatellite loci used for analysis (NECHTELBERGER et al., 2001) were; S0005, S0090, S0101, S0155, S0355, S0386, SW24, SW240, SW857, SW951, which are also accepted by FSAVE (Foundation Safeguard for Agricultural Varieties in Europe) DNA amplification was performed in a Hybaid Thermal Cycler. Amplified fragments were resolved on ABI310 Automatic Fragment Analyzer. Fragment length allocation was made by Genescan and Genotyper programs.

In the year of 2003 non-relative founder animals (50 samples/herds) were selected from Swallow-Belly, Red and Blond Mangalica herds. In 2004 another 132 samples were analysed. Statistical analyses were performed on each group (collected in 2003 and 2004) separately. The results were the same for both cases (data not shown). In the following sections analyses of the whole dataset are interpreted. 
The following programs were used for data processing and crosscheking the results (MAUDET et al., 2002): Microsatellite Toolkit (PARK, 2001) has been used for data cheking and formatting in order to meet the input format of Dispan (TATSUYA, 1993) (Dispan has been used for calculation of genetic distances Dst and Da (NEI, 1972; 1978, 1983) and for construction of phylogenetic trees), Structure (FALUSH et al., 2003), Geneclass (PIRY et al., 2004), GDA (for calculation of Fst) (LEWIS and ZAYKIN, 2001). SPSS were applied in case of discrimination and PCA analysis.

\section{Results and Discussion}

Testing the hypothesis that the Mangalica individuals belong to one indistinguishable group, discrimination analysis was performed by SPSS (independents were the allele lengths of different loci). Since the first and second functions describe 79.6 and $20.4 \%$ variance and show strong correlation (0.817 and 0.582$)$ between the discriminant scores and the groups, the allele lengths can be used for differentiation. It has been revealed that the means of presumed three groups are significantly different at $\mathrm{p} \leq 0.000$ so more than one group must exist within the population and the hypothesis must be rejected. As for classification result $83.5 \%$ of originally grouped cases were correctly classified if prior probabilities were set to equal for them (each individual has equal chance to belong to any group), indicating that they were apparently correctly assigned to their breeds on phenotypic basis by the breeders.

The analytical approach was further tested by Structure program, where individuals are assigned to populations according to the allele frequencies at each locus. Prior population information was involved in order to lower the number of iterations and subsequently computer time to achieve convergence in values of summary statistics (PRITCHARD et al., 2000). When population information was not used (admixture model), the probabilities of belonging to a cluster were lowered from $92 \%$ to $82 \%$ referring individuals, correctly identified to their groups when the same number of iterations were applied. When cluster number (K-value) was set to three, control DU individuals were placed into the middle of the graphical, triangle output of Structure program as a distinguishable group (Fig. 1). Setting $\mathrm{K}$ to four, Durocs have fallen into the fourth cluster. We have also set the prior population information incorrectly in some cases of arbitrary selected individuals ( 1 to 10 in a time). The individuals treated on that way, assigned to their previously defined cluster correctly in spite of the artificial, false input. The few samples, fallen into other clusters than their originally denoted ones (Fig. 1), will be checked for pedigree later to decipher the possible roots of the observed phenomenon. Similar assignments (84-90\% correctly identified individuals) were obtained carrying out direct and exclusion simulation tests by Geneclass program under distance or likelihood based methods. Altogether these programs demonstrated that Mangalicas are belonging to three distinct clusters and they can be efficiently assigned to their groups.

Genetic distances (Da, Ds, Fst, at Table 1.) and pylogenetic trees constructed by unweighted pair group-method with aritmethic mean or neighbour-joining method (Fig. 2). The distance values (e.g.: Fst is from 0.064 to 0.099) indicate the three breeds are moderately differentiated and reflect to the documented history, that BM and SM are closer to each other (Fst=0.064) than each of them to the RM (Fst=0.094 and 0.099, respectively). 


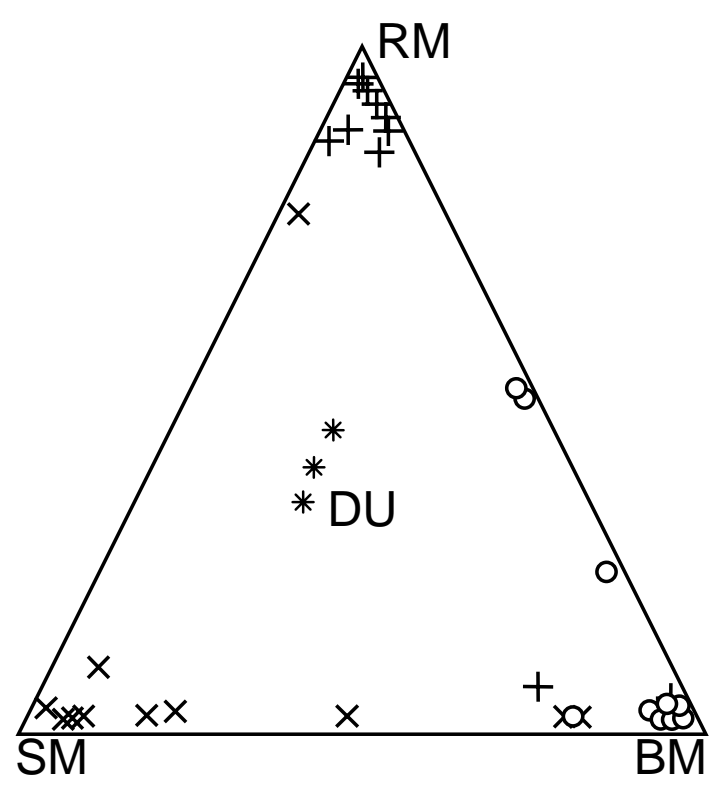

Fig. 1: Manually redrawn graphical output of Structure program. Mangalica individuals fall within different clusters as denoted in the corners of triangle. Cluster number was set to 3, iteration number was 125 . The signs $\mathrm{x}$, + , o, * are for Swallow-Belly (SM), Red (RM), Blond Mangalica (BM) and Duroc samples, respectively (Graphische Darstellung der Strukturen der Mangalitza Populationen)

Table 1

Distances of Swallow-Belly (SM), Blond (BM) and Red (RM) Mangalicas. In each box the first row is for standard genetic distances -Ds- and errors of Ds; second row: Da; third raw: Fst. (Genetische Distanzen der drei Mangalitza Populationen)

\begin{tabular}{lll}
\hline & SM & BM \\
\hline BM & $0.1138(0.0426)$ & - \\
& 0.0845 & - \\
& 0.0641 & - \\
RM & $0.2002(0.0775)$ & $0.1992(0.0726)$ \\
& 0.1883 & 0.1618 \\
& 0.0994 & 0.0945 \\
\hline
\end{tabular}

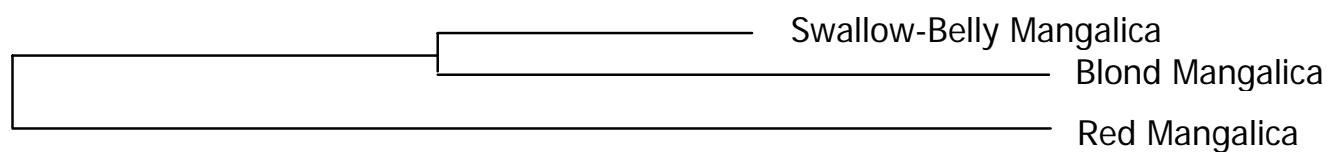

Fig. 2: DaNJ tree of Mangalica breeds (DaNJ Baumstruktur der Mangalitza Populationen)

In order to test the validity of our deduction (Mangalicas are individuals of three distinct breeds) from other aspects, the population was tested for clusters (PRITCHARD et al., 2000) based on computed posterior probabilities by Structure program. When clusters checked: on i.) all the genotyped samples without farm information or ii.) within a farm with three different Mangalica breeds; the most probable cluster value was three in concordance with our previous findings. If all farms were involved with information of location, it had effect on $\mathrm{K}$ value (e.g.: 
animals from three farms -each farm having SM, BM and RM- have fallen into nine clusters, with the highest probability).

Since geographical location displayed effect on the cluster number, we checked the extent of that impact by principal component analysis based on genotypes. The first two components describe 46 and $33 \%$ of the variance. Their eigenvalues are 7.8 and 2.7 respectively. The third component (eigenvalue is 1.8 ) is responsible for $7 \%$ of the total variance and contains the farm locations with the weight of 0.19 (Table 2). This minor effect -not influencing the result of our discrimination analysis- explain the increased number of clusters in the latter case where farm information was incorporated into the cluster estimation. As a consequence, farm effect makes it possible to draw fine structure of SM, BM and RM breeds from the standpoint of farm relations. Genetic distances were also determined within breeds concerning geographical locations or farms (data not shown). The results can give hints to the farmers to select appropriate individuals for mating within breeds.

Table 2

Principal component analysis of Mangalica populations (Hauptkomponentenanalyse der Mangalitza Populationen)

\begin{tabular}{llll}
\hline & \multicolumn{2}{l}{ Components } & 3 \\
\hline FARM & 1 & 2 & 0.193 \\
SW24 & 0.550 & 0.504 & \\
SW240 & -0.163 & & \\
SW951 & -0.299 & 0.196 & \\
SW857 & -0.128 & -0.244 & 0.692 \\
S0155 & 0.568 & 0.133 & \\
S0386 & 0.743 & 0.273 & -0.307 \\
S0101 & 0.636 & -0.763 & \\
S0005 & 0.843 & 0.379 & 0.528 \\
S0090 & 0.686 & 0.606 & \\
S0355 & 0.583 & 0.503 & \\
\hline
\end{tabular}

(absolute values below 0.1 are not shown)

The applied microsatellites approach can be used to assign individuals to their subpopulations with high probability $(0.8$ - 0.9). For further help, simple assignation can be completed employing individual alleles such as; locus S0101: allele 198 is missing in SM, allele 218 is missing in RM, locus SW240: allele 108 is missing in SM, locus SW857: allele 143 is missing in BM, however more adequate criterion for allele based assignation can only be given if the whole population is going through the tests.

The analysis supports the national program originally based on traditional approach. It enhances the point of view, that the three Mangalica populations can not be handled as coloured varieties of Mangalica; Swallow-Belly, Blond and Red are indeed separate breeds.

Extending the investigation, we are going to analyse the whole population or family lines of each Mangalica breed, in order to reveal reason of failed assignation in case of several animals. We also plan to gain molecular genetic data from other breeds preferably including larger data sets from other biodiversity projects- to prove or reject that Blond was created first among Mangalicas. 


\section{Acknowledgement}

We express our gratitude to the National Association of Mangalica Breeders for the cooperation and to Dr. Albano Beja-Pereira for his valuable suggestions. This work was supported by national grant no.: 4/0021/2002 in the framework of Széchenyi-plan.

\section{References \\ ACHIEVEMENT IN MANGALITZA CROSSBREEDING.}

In SAVE-DAGENE International Meeting of Mangalica Breeders in Budapest (2001)

ABERLE, K.S.; DISTL, O.:

Domestication of the horse: results based on microsatellite and mitochondrial DNA markers. Arch. Tierz., Dummerstorf 47 (2004) 6, 517-535

CZILERT, R.:

Conceptions of animal breeding (Állattenyésztési eszmék) Pest Nyomtatott Hertz Jánosnál XXIV-XXV, (1859), 139-148

EGERSZEGI, I.; RÁTKY, J.; SOLTI, L.; BRÜSSOW, K.-P.:

Mangalica - an indigenous swine breed from Hungary (Review). Arch. Tierz., Dummerstorf 46 (2003), 245-256

ENESEI DORNER, B.:

Swine breeding and fattening (A sertés tenyésztése és hízlalása) Bp. publisher; Atheneum Irodalmi es Nyomdai R. T. 81-84 (1925), 134-141

FALUSH, D.; STEPHENS, M.; PRITCHARD, J.K.:

Inference of Population Structure Using Multilocus Genotype Data: Linked Loci and Correlated Allele Frequencies. Genetics 164 (2003), 1567-1587

HANDIWIRAWAN, E.; NOOR, R. R.; MULADNO; SCHÜLER, L.:

The Use of HEL9 and INRA035 Microsatellites as Specific Markers for Bali Cattle. Arch. Tierz.,

HANKÓ, B.: Dummerstorf 46 (2003), 503-512

Ancient domestic animals of Hungary (Õsi magyar háziállataink). Debrecen Tiszántúli Mg-i Kamara. (1940)

JANßEN, M.; WEIMANN, CH.; BRANDT, H.; GAULY, M.; ERHARDT, G.:

Parasitological parameters after artificial infections with Haemonchus contortus in Merinoland sheep and its association to genetic markers on chromosome 20. Arch. Tierz., Dummerstorf 47 (2004), 36-42

JORDANA, J.; FOLCH, P.; ARANGUREN, J.A.:

Microsatellite analysis of genetic diversity in the Catalonian donkey breed. J. of Anim. Breed. Genet., 118 (2001), 57-63

LEWIS, P. O.; ZAYKIN, D.:

Genetic Data Analysis: Computer program for the analysis of allelic data. Version 1.0 (d16c). 2001, Free program distributed by the authors over the internet from http://lewis.eeb.uconn.edu/lewishome/software.html

MAUDET, C.; MILLER, C.; BASSANO, B.; BREITENMOSER-WÜRSTEN, C.; GAUTHIER, D.; OBEXERRUFF, G.; MICHALLET, J.; TABERLET, P.; LUIKART, G.:

Microsatellite DNA and recent statistical methods in wildlife management: applications in Alpine Ibex (Capra ibex (ibex)). Molecular Ecology, 11 (2002), 421-436

MATEUS, J.C.; PENEDO, M.C.; ALVES, V.C.; RAMOS, M.; RANGEL-FIGUEIREDO, T.:

Genetic diversity and differentiation in Portuguese cattle breeds using microsatellites. Anim Genet., 35 (2004), 106-113

MICKLICH, D.; MATTHES, H.D.:

Outdoor keeping of sows of different breeds in a location of floodplain wood. Arch. Tierz., Dummerstorf 42 (1999), 161-173

NEI, M.:

Genetic distances between populations. Am. Nat., 106 (1972), 283-292

NEI, M.:

Estimation of average heterozygosity and genetic distance from a small number of individuals. Genetics, 89 (1978), 583-590

NECHTELBERGER, D.; KALTWASSER, C.; STUR, I.; MEYER, JN.; BREM, G.; MUELLER, M.; MUELLER, S.: 
DNA microsatellite analysis for parentage control in Austrian pigs. Anim. Biotechnol., 12 (2001), 141144

PIRY, S.; ALAPETITE, A.; CORNUET, J.-M.; PAETKAU, D.; BAUDOUIN, L.; ESTOUP, A.:

GeneClass2: A Software for Genetic Assignment and First-Generation Migrant Detection. Journal of Heredity 95 (2004), 536-539

PARK, S.D.E.:

Trypanotolerance in West African Cattle and the Population Genetic Effects of Selection [ Ph.D. thesis ] University of Dublin, 2001

PRITCHARD, J.K.; STEPHENS, M.; DONELLY, P.:

Inference of population structure using multilocus genotype data. Genetics, 155 (2000), 945-959

SCHWARZ, S.; PRESUHN, U.; KALM, E.; REINSCH, N.:

Characterizing polymorphism and multiplex feasibility of 142 microsatellite markers from a ŚWITOŃSKI, M. commercial German Landrace line. Arch. Tierz., Dummerstorf 48 (2005), 490

TATSUYA, O.;

Marker genome maps of the sheep and goat. Arch. Tierz., Dummerstorf 47 (2004), 4-9

Institute of Molecular Evolutionary Genetics, The Pennsylvania State University, 328 Mueller Laboratory, University Park, PA 16802, USA, Copyright 1993, http://mep.bio.psu.edu/readme.html

Received: 2005-11-18

Accepted: 2006-05-19

Author's addresses

Dr. ATTILA ZSOLNAI*, PhD; Prof. LÁSZLÓ FÉSÜS, DSc, Dr. ISTVÁN ANTON, PhD

Research Institute for Animal Breeding and Nutrition,

H-2053 HERCEGHALOM, Gesztenyés u.1.

HUNGARY

* Corresponding Author

E-Mail: attila.zsolnai@gmail.com

Dr. LÁSZLÓ RADNÓCZY, PhD

Research Institute for Agricultural Quality Control, H-1024 BUDAPEST, Keleti K. u. 24.

HUNGARY 